Thorax, 1980, 35, 277-281

\title{
Sarcoid pleural effusion: three cases and review of the literature
}

\author{
A J NICHOLLS, J A R FRIEND, AND J S LEGGE
}

From the Chest Clinic, City Hospital, Aberdeen

ABSTRACT Pleural sarcoidosis is rare-it is little recognised in Britian although several cases have been reported in the international literature. Three white men with pleural effusions caused by sarcoidosis have been seen in a two-year period when approximately 60 new cases of thoracic sarcoidosis have presented. In one patient a recurrent massive effusion was only diagnosed as being caused by sarcoidosis after thoracotomy, and in two further patients small symptomatic pleural effusions were present at the onset of typical sarcoidosis. Two patients were successfully treated with steroids and the third improved spontaneously. Percutaneous biopsy is not always helpful in diagnosing pleural sarcoidosis, but a lymphocytic, often blood-stained, pleural aspirate is highly characteristic. While other diseases may coexist, a pleural effusion in a patient with histologically proven sarcoidosis is more likely to be caused by the primary disease than by any other condition.

Pleural involvement in sarcoidosis has been regarded as exceptional in the British literature. ${ }^{12}$ Although recent reports have described acute pleurisy without effusion ${ }^{3}$ and retrosternal pain, ${ }^{4}$ sarcoidosis is not widely regarded as a cause of pleural effusion in the United Kingdom.

In Britain there has only been one published case occurring in a West Indian living in London, ${ }^{5}$ whereas there have been many well-documented cases of pleural sarcoidosis with effusion in the international literature, several of which have been reviewed Chusid and Siltzbach ${ }^{6}$ and by Wilen and colleagues. ${ }^{7}$

We present here three cases of sarcoidosis in white men living in Scotland, all of whom developed symptomatic pleural effusions not caused by other conditions.

\section{Case reports}

\section{CASE 1}

A 28-year-old Scottish white male oil-rig engineer developed right uveitis in March 1976. His chest radiograph showed bilateral hilar and paratracheal lymphadenopathy and lower zone pulmonary infiltration. Sarcoidosis was diagnosed and prednisolone $40 \mathrm{mg}$ daily was given. His uveitis cleared within a month.

In April 1976 he was asymptomatic, steroids

Address for reprint requests: Dr AJ Nicholls, Department of Medicine University of Aberdeen, Foresterhill, Aberdeen AB9 2ZD. having been stopped. His tuberculin reaction (10 TU) was negative, having been Heaf grade III positive in 1963. Spirometry, lung volumes, and diffusing capacity were normal, but there was mild hypoxaemia $\left(\mathrm{PaO}_{2} 9 \cdot 68 \mathrm{kPa}\right)$. No further treatment was given and he remained well for the next six months.

In October 1976 this patient developed left cervical and bilateral axillary lymphadenopathy and hepatosplenomegaly. His radiograph was unchanged and a blood count was normal. Both a liver biopsy and a cervical lymph node biopsy showed non-caseating granulomata typical of sarcoidosis. Pulmonary function testing was unchanged and no treatment was given. $\mathrm{He}$ remained well for the rest of 1976 .

In January 1977 he complained of left pleuritic chest pain and progressive dyspnoea. He had a large left pleural effusion (fig 1) and increased hepatosplenomegaly. There were no signs of venous disease in the legs. Pleural aspiration yielded a litre of bloodstained fluid containing eosinophils, lymphocytes, and neutrophil polymorphs which was sterile on culture. A Mantoux test (10 TU) was negative. A further three litres of fluid were aspirated at subsequent thoracenteses, with the same negative bacteriology. Pleural punch biopsy did not yield specific histology. Sputum was repeatedly negative for acid-fast bacilli on direct film and culture. Bone marrow obtained by aspiration showed reactive changes, 


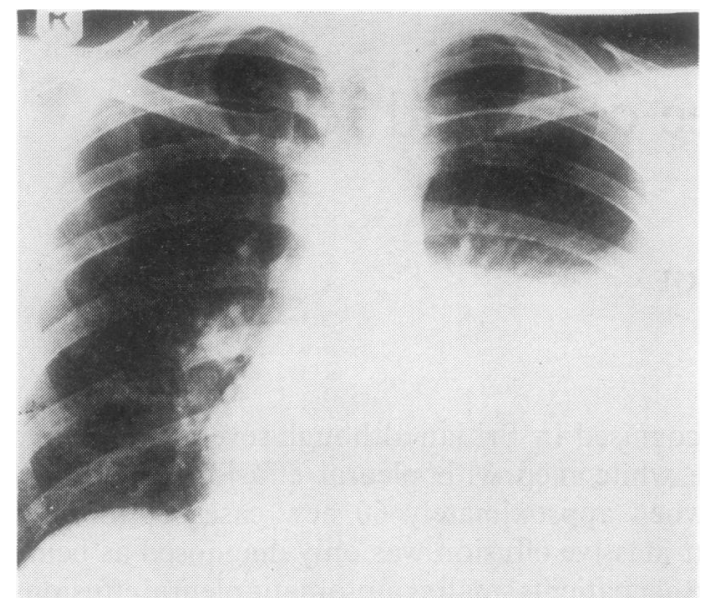

Fig 1 Case 1. January 1977, showing a large left pleural effusion.

and was sterile on culture. A repeat Mantoux test with 100 tuberculin units was negative.

An open pleural and lung biopsy was performed in view of further accumulation of fluid $-2600 \mathrm{ml}$ of serosanguinous fluid was aspirated and culture was again sterile. The lung and parietal pleura were slightly reddened and fibrinous exudate was present, but no obvious superficial pulmonary lesion was seen. Lung histology showed the changes of sarcoidosis underlying the visceral pleura (fig 2) and the parietal pleura showed nonspecific inflammatory change.

Treatment with prednisolone $40 \mathrm{mg}$ daily was started and in addition conventional doses of rifampicin, isoniazid, and ethambutol were given as the results of the the tuberculosis cultures were not available by then. The effusion did not recur and the lymphadenopathy and hepatosplenomegaly regressed partially. Two years later he remains in good health on $5 \mathrm{mg}$ prednisolone daily, although liver and spleen remain palpable $5 \mathrm{~cm}$ below the costal margins. His chest radiograph shows persistent lower zone shadowing, but pulmonary function tests have not changed significantly.

\section{CASE 2}

A 27-year-old Scottish white male stonemason developed erythema nodosum and a dry cough in February 1978. Two months later he complained of left-sided pleuritic chest pain and became progressively more breathless. Physical examination was normal apart from signs of a left pleural effusion. A chest radiograph confirmed the effusion and also showed bilateral hilar lymphadenopathy.

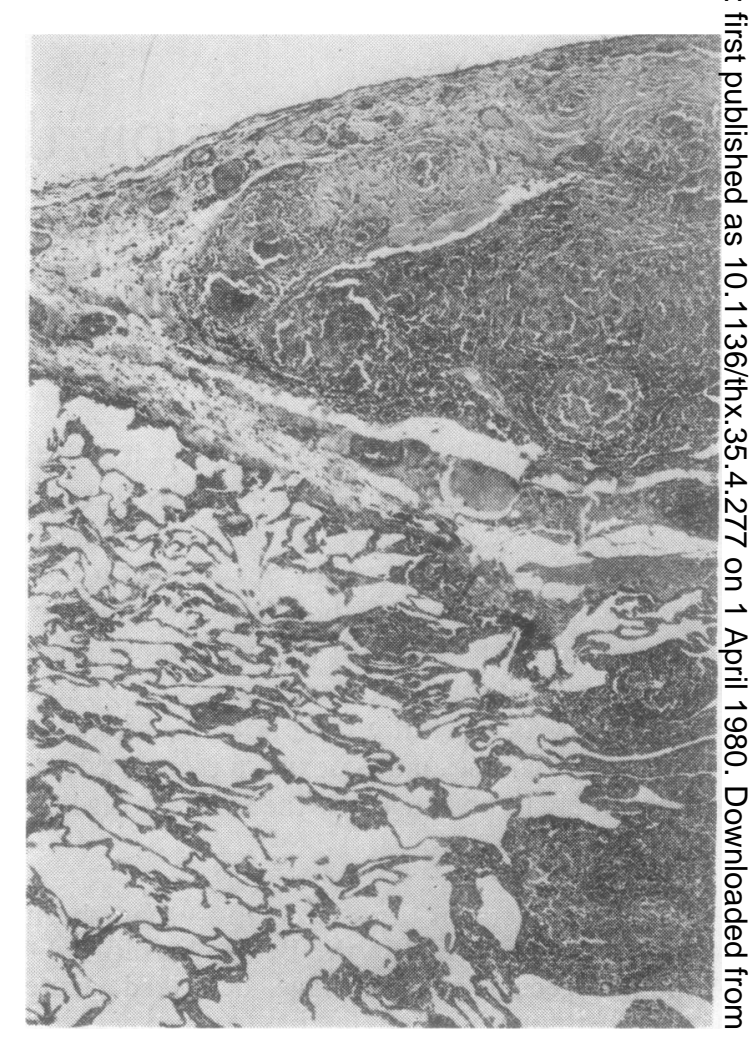

Fig 2 Case 1. Epithelial cell granulomata in pleura and underlying lung. Haematoxylin and eosin, original magnification $\times 64$.

Pleural aspiration yielded a litre of slightly: bloodstained fluid containing lymphocytes, histiocytes, and mesothelial cells. Pleural punch biopsy showed fibrinous granulation-like tissue, $\stackrel{0}{\circ}$ but no granulomata were identified. A Mantoux test was negative at $10 \mathrm{TU}$, but positive $(20 \mathrm{~mm}$ ? diameter induration) at $100 \mathrm{TU}$. Culture of the pleural fluid was negative for tubercle bacilli and other organisms, and no sputum was produced. AN Gallium scan showed diffuse uptake in the mediastinum, liver, and abdominal lymph nodes, 0 compatible with a lymphoma or sarcoidosis. Aw Kveim test (Colindale $\mathrm{K}$ 19/1/13) subsequently showed typical sarcoid granulomata on biopsy.

He received no drug therapy and returned to work three weeks later with a little residual fluid ${ }^{\text {? }}$ still present. By November 1978, nine months? after the onset of his symptoms, he was com을 pletely well with a normal chest radiograph.

\section{CASE 3} A 25-year-old white male labourer, American by birth and of Italian ancestry, presented in Aprito 


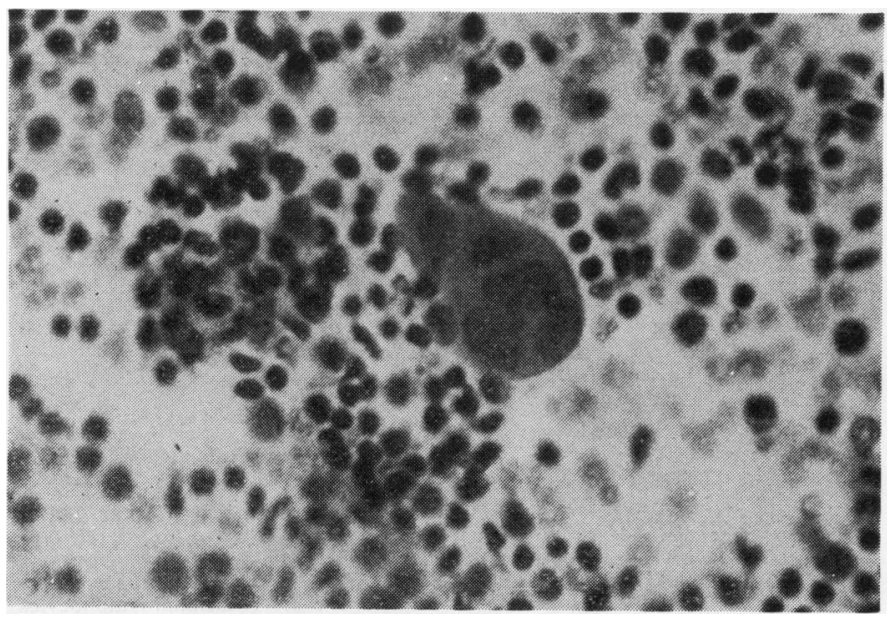

Fig 3 Case 3. Pleural fluid cyto!ogy showing a multinucleate giant cell surrounded by numerous lymphocytes and erythrocytes. Papanicolou stain.

1978 with left-sided pleuritic chest pain, night sweats, and dyspnoea on mild exertion. He had lost $10 \mathrm{~kg}$ in the previous few months.

Clinical examination revealed signs of a small left pleural effusion, but was otherwise normal. A chest radiograph confirmed the effusion, and also showed hilar and paratracheal lymphadenopathy and pulmonary infiltration in the left mid zone and right base. Aspiration of the effusion yielded $200 \mathrm{ml}$ of sterile serous fluid containing eosinophils and lymphocytes. Cytological examination of the fluid showed occasional giant cells (fig 3 ). Sputum was negative for tubercle bacilli on direct film and culture, and a Mantoux reaction (100 TU) was negative. Pulmonary function tests showed a restrictive ventilatory defect with reduced total lung volume and diffusing capacity. A paratracheal lymph node removed at mediastinoscopy showed typical features of sarcoidosis. Pleural punch biopsy was unsuccessful.

The effusion had not recurred by June 1978, but in view of persistent left pleuritic pain, breathlessness, and abnormal lung function prednisolone $20 \mathrm{mg}$ daily was started. His symptoms resolved, the lung volumes improved, and the single breath carbon monoxide transfer factor rose from 7.3 to $10.55 \mathrm{mmol} / \mathrm{min} / \mathrm{kPa}$ (predicted $12 \cdot 8$ ). He remains on prednisolone $5 \mathrm{mg}$ daily and the effusion has not recurred.

\section{Discussion}

Pleural involvement with sarcoid granulomata is unusual, but has been recognised since 1933 when Schaumann ${ }^{8}$ described it as a necropsy finding in a 45-year-old white man. Although sporadic case reports have appeared since then and have been the subject of several recent reviews, ${ }^{6} 7910$ the incidence of the condition is not always apparent from the case reports. However, several authors have quoted their findings for the prevalence of pleural sarcoidosis, and these are summarised in table 1 . It should be noted that this is a heterogeneous collection of data, and the criteria for diagnosis of pleural sarcoid are not always stated. Nonetheless, most authors find a prevalence of $0-5 \%$ for the condition although Wilen et $a l^{7}$ and Brun et al $^{22}$ suggest it is much more common. Our own experience suggests a prevalence of around $5 \%$, for the three cases described in this paper have been seen out of a series of approximately 60 new cases of thoracic sarcoidosis attending a chest clinic over two years.

The diagnosis of pleural sarcoidosis depends initially on histological demonstration of the disease in biopsies from conventional sites (liver or lymph node), or by a Kveim test. Thereafter, definitive evidence of pleural granulomata may

Table 1 Reported prevalence of pleural sarcoidosis

\begin{tabular}{|c|c|c|c|}
\hline \multirow{2}{*}{$\begin{array}{l}\text { Author(s) } \\
\text { Chusid and Siltzbach6 }\end{array}$} & Number of patients & \multicolumn{2}{|c|}{$\begin{array}{l}\text { Cases of pleural } \\
\text { sarcoidosis }(\%)\end{array}$} \\
\hline & 950 & 7 & $(<1)$ \\
\hline Ellis and Renthal 11 & 127 & 1 & $(<1)$ \\
\hline Freundlich et al 12 & 300 & 4 & (1 3) \\
\hline Israel and Sones 13 & 160 & 3 & (2) \\
\hline Kirks et al 14 & 150 & 5 & (3) \\
\hline Longcope and Freiman 15 & 160 & 2 & (13) \\
\hline McCort et al 16 & 28 & 2 & (4) \\
\hline Maycock et al ${ }^{17}$ & 140 & $\mathbf{0}$ & (Nil) \\
\hline Nitter ${ }^{18}$ & 90 & 0 & (Nil) \\
\hline Rabinowitz et al 19 & 198 & 10 & (5) \\
\hline Scadding 1 & 234 & 2 & $(<1)$ \\
\hline Sharma and Gordonson 20 & 100 & 6 & (6) \\
\hline Siltzbach 21 & 311 & 3 & (3) \\
\hline Wilen et $a^{7}$ & 223 & 23 & (11) \\
\hline Brun et $a l^{22}$ & Anecdotal evidence & & $(\sim 10 \%)$ \\
\hline
\end{tabular}


Table 2 Pleural fluid characteristics in cases where details are stated (NS=not stated)

\begin{tabular}{|c|c|c|c|}
\hline Author(s) & Naked eye appearance & Protein content & Cells \\
\hline $\begin{array}{l}\text { Tice and Sweany } 23 \\
\text { Brun } e t \text { al } 22 \\
\text { Berte and Pfotenhauer } 24\end{array}$ & $\begin{array}{l}\text { Serosanguinous } \\
\text { Serofibrinous } \\
\text { Serosanguinous }\end{array}$ & $\begin{array}{l}\text { NS } \\
\text { "exudate" } \\
51 \mathrm{~g} / 1\end{array}$ & $\begin{array}{l}\text { NS } \\
80 \% \text { lymphocytes } \\
67 \% \text { lymphocytes } \\
29 \% \text { eosinophils }\end{array}$ \\
\hline $\begin{array}{l}\text { Plancherel } 25 \\
\text { Silviera and Benevides } 26 \\
\text { Lebacq }^{27} \text { (three cases) } \\
\text { Kovnat and Donohue } \\
\text { Macquet } \text { et al }^{28} \\
\text { Press et al } 30 \\
\text { Selroos } \\
{ }^{31} \text { (four cases) }\end{array}$ & $\begin{array}{l}\text { Sanguinous } \\
\text { Turbid } \\
\text { All serous } \\
\text { Straw-coloured } \\
\text { Serofibrinous } \\
\text { Serous } \\
\text { (i) Serous } \\
\text { (ii) Serous } \\
\text { (iii) Serous } \\
\text { (iv) Serous }\end{array}$ & $\begin{array}{l}\text { NS } \\
\text { NS } \\
\text { all "transudates" } \\
50 \mathrm{~g} / 1 \\
\mathrm{NS} \\
\text { "transudate" } \\
40 \mathrm{~g} / 1 \\
\text { "exudate" } \\
\text { "exudate" } \\
20 \mathrm{~g} / 1\end{array}$ & $\begin{array}{l}\text { NS } \\
\text { NS } \\
\text { NS } \\
\text { occasional erythrocytes } \\
93 \% \text { lymphocytes } \\
62 \% \text { lymphocytes } \\
98 \% \text { lymphocytes } \\
\text { NS } \\
\text { NS } \\
88 \% \text { lymphocytes }\end{array}$ \\
\hline $\begin{array}{l}\text { Aberg et al } 32 \\
\text { Budillon } \text { et } a l^{33}\end{array}$ & $\begin{array}{l}\text { Chylous } \\
\text { Straw-coloured }\end{array}$ & NS & $\begin{array}{l}\text { NS } \\
\text { NS }\end{array}$ \\
\hline $\begin{array}{l}\text { Everett and Overholt } 34 \text { (two cases) } \\
\text { Nelson and Loudon } 35\end{array}$ & $\begin{array}{l}\text { Both serous } \\
\text { Serous }\end{array}$ & $\begin{array}{l}\text { NS } \\
\text { "exudate" }\end{array}$ & $\begin{array}{l}\text { NS } \\
98 \% \text { lymphocytes }\end{array}$ \\
\hline Kirks et al ${ }^{14}$ (five cases) & NS & all "exudates" & NS \\
\hline Wilen et al ${ }^{7}$ (eight cases) & All serous & all $<23 \mathrm{~g} / 1$ & $\begin{array}{l}\text { three cases-occasional lymphocytes } \\
\text { five cases-no cells }\end{array}$ \\
\hline Chusid and Siltzbach ${ }^{6}$ (four cases) & $\begin{array}{l}\text { (i) Yellow } \\
\text { (ii) Yellow, turbid } \\
\text { (iii) Sanguinous } \\
\text { (iv) Serosanguinous, turbid }\end{array}$ & $\begin{array}{l}\text { "exudate" } \\
\text { "exudate", } \\
\text { "exudate" } \\
\text { "exudate" }\end{array}$ & $\begin{array}{l}100 \% \text { lymphocytes } \\
99 \% \text { lymphocytes } \\
\text { NS } \\
100 \% \text { lymphocytes }\end{array}$ \\
\hline Beekman et al (two cases) & $\begin{array}{l}\text { (i) Sanguinous } \\
\text { (ii) Yellow }\end{array}$ & $\begin{array}{l}49 \mathrm{~g} / 1 \\
40 \mathrm{~g} / 1\end{array}$ & $\begin{array}{l}66 \% \text { lymphocytes } \\
61 \% \text { lymphocytes }\end{array}$ \\
\hline Mikhail et al 5 & NS & NS & many lymphocytes \\
\hline Sharma ${ }^{10}$ (eight cases) & $\begin{array}{l}\text { (i) Cloudy yellow } \\
\text { (ii) Straw } \\
\text { (iii) Straw } \\
\text { (iv) Serous } \\
\text { (v) Turbid } \\
\text { (vi) Serosanguinous } \\
\text { (vii) Serous } \\
\text { (viii) Yellow }\end{array}$ & $\begin{array}{l}65 \mathrm{~g} / 1 \\
38 \mathrm{~g} / 1 \\
40 \mathrm{~g} / 1 \\
57 \mathrm{~g} / 1 \\
46 \mathrm{~g} / 1 \\
56 \mathrm{~g} / 1 \\
36 \mathrm{~g} / 1 \\
48 \mathrm{~g} / 1\end{array}$ & $\begin{array}{l}90 \% \text { lymphocytes } \\
\text { "lymphocytes" } \\
\text { no cells } \\
\text { no cells } \\
\text { "predominantly lymphocytes" } \\
\text { NS } \\
\text { a few mononuclear cells } \\
\text { no cells }\end{array}$ \\
\hline Present study (three cases) & $\begin{array}{l}\text { (i) Sanguinous } \\
\text { (ii) Serosanguinous } \\
\text { (iii) Serous }\end{array}$ & $\begin{array}{l}53 \mathrm{~g} / 1 \\
42 \mathrm{~g} / 1 \\
46 \mathrm{~g} / 1\end{array}$ & $\begin{array}{l}\text { lymphocytes, eosinophils } \\
\text { lymphocytes, eosinophils, histocytes } \\
90 \% \text { lymphocytes giant cells }\end{array}$ \\
\hline All cases & $9 / 47$ Sanguinous or serosanguinous & $28 / 41$ exudates & $\begin{array}{l}22 / 31 \text { predominantly lymphocytic } \\
8 / 31 \text { no cells }\end{array}$ \\
\hline
\end{tabular}

sometimes be obtained by percutaneous biopsy, but this technique is not specially reliable. Our finding of non-diagnostic biopsies in all three cases agrees with the experience of Sharma ${ }^{10}$ who found positive pleural histology in only two of his eight cases. However, pleural fluid analysis can be of a greater value, as table 2 shows. The effusion is not infrequently bloodstained, usually an exudate, and (when cellular) contains predominantly lymphocytes. Thus, although there are no distinguishing features specific for sarcoidosis or different from tuberculosis, other possible causes for the effusion are effectively ruled out. While sarcoidosis and tuberculosis can coexist, ${ }^{1}$ such an occurrence is rare, and no cases have been reported in which a pleural effusion in a patient with histologically proven sarcoidosis has been shown to be the result of tuberculosis. Thus once conventional bacteriological investigations have excluded tuberculosis, the diagnosis of pleural sarcoidosis can be made with confidence. It has been suggested that pleural sarcoidosis is rare in the absence of widespread parenchymal lung disease, ${ }^{14}$ but this is not a constant enough feature to be of diagnostic value. It remains to be shown, however, if pleural disease can exist as the sole manifestation of sarcoidosis.

The management of a sarcoid pleural effusion $\rightarrow$ depends on the symptoms and biopsy evidence of disease. In the absence of symptoms one can $N$ expect an effusion to resolve spontaneously ${ }^{20}$ but if the effusion is symptomatic or recurrent, resolution will occur with steroid therapy. If a biopsy $\mathcal{\omega}$ has given unequivocal evidence of pleural noncaseating granulomata, no other treatment ise needed. But if a histology is non-specific, it may $\mathbb{D}$ be wise to add antituberculous therapy until $\stackrel{?}{-}$ negative bacteriological results are obtained.

Sarcoidosis is undoubtedly a cause of pleural $\frac{O}{\Phi}$ effusion in Britain as it is in the rest of the world, and awareness of the entity should increase $\mathbb{Q}$ its diagnosis. Indeed, sarcoidosis is the most likely cause of an effusion in patients with other 8 evidence of the disease. 
We should like to thank $\mathrm{Mr} \mathrm{AV}$ Foote for performing the thoracotomy in case $1, \mathrm{Mr}$ JS Cockburn for the mediastinoscopy in case $3, \mathrm{Dr}$ JG Simpson for the photomicrograph, Dr JE McGregor for the cytology, and the Radiology and Bacteriology Departments of the City Hospital, Aberdeen for valuable assistance.

\section{References}

1 Scadding JG. Sarcoidosis. London: Eyre and Spottiswoode, 1967.

2 Crofton J, Douglas A. Respiratory diseases. Second edition. Oxford: Blackwell Scientific Publications, 1975; 415-7.

3 Gardiner IT, Uff JS. Acute pleurisy in sarcoidosis. Thorax 1978; 33:124-7.

4 Hendrick DJ, Blackood R, Black JM. Chest pain in the presentation of sarcoidosis. $\mathrm{Br} J$ Dis Chest 1976; 70:206-10.

5 Mikhail JR, Lovell D, McGhee KJ. Sarcoidosis presenting with a pleural effusion. Tubercle 1976; 57:226-8.

6 Chusid EL, Siltzbach LE. Sarcoidosis of the pleura. Ann Intern Med 1974; 81:190-4.

7 Wilen SB, Rabinowitz JG, Ulreich S, Lyons HA. Pleural involvement in sarcoidosis. Am J Med 1974; 57:200-9.

8 Schaumann J. Étude anatomo-pathologique et histologique sur les localisations viscérales de la lymphogranulomatose bénigne. Bull Soc Franc Dermat Syph 1933; 40:1167-78.

9 Beekman JF, Zimmett SM, Chun BK, Miranda AA, Katz S. Spectrum of pleural involvement in sarcoidosis. Arch Intern Med 1976; 136:323-30.

10 Sharma OP. Sarcoidosis: unusual pulmonary manifestations. Postgrad Med 1977; 61:67-73.

11 Ellis K, Renthal G. Pulmonary sarcoidosis. Roentgenographic observations on course of diease. Am J Roentgenol Radium Ther Nucl Med 1962; 88:1070-83.

12 Freundlich IM, Libshitz HI, Glassman LM, Israel HL. Sarcoidosis. Typical and atypical thoracic manifestations and complications. Clin Radiol 1970; 21:376-83.

13 Israel HL, Sones M. Sarcoidosis. Arch Intern Med 1958; 102:766-76.

14 Kirks DR, McCormick VD, Greenspan RH. Pulmonary sarcoidosis. Roentgenologic analysis of 150 patients. Am J Roentgenol Radium Ther Nucl Med 1973; 117:777-86.

15 Longcope WT, Freiman DG. A study of sarcoidosis. Medicine (Baltimore) 1952; 31:1-132.

16 McCort JJ, Wood RH, Hamilton JB, Ehrlich DE. Sarcoidosis: clinical and roentgenographic study of 28 proved cases. Arch Intern Med 1947; 80:293-321.
17 Maycock RL, Bertrand P, Morrison CE, Scott JH. Manifestations of sarcoidosis. Analysis of 45 cases with a review of nine series selected from the literature. Am J Med 1963; 35:67-89.

18 Nitter L. Changes in the chest roentgenogram in Boeck's sarcoid of the lungs. Acta Radiol 1953; suppl 105.

19 Rabinowitz JG, Ulreich S, Soriano C. The usual unusual manifestations of sarcoidosis and the "hilar haze"- a new diagnostic aid. Am J Roentgenol Radium Ther Nulc Med 1974; 120:821-31.

20 Sharma OP, Gordonson J. Pleural effusion in sarcoidosis: a report of six cases. Thorax 1975; 30:95-101.

21 Siltzbach LE. Sarcoidosis: clinical features and management. Med Clin North Am 1967; 51: 483-502.

22 Brun J, Perrin-Fayolle $M$, Ledoux A, Biot N. Pleurésie chronique intarissable et atteintes pleurales diverses au course de la sarcoïdose de Besnier-Boeck-Schaumann. Poumon Coeur 1961; 17:477-92.

23 Tice F, Sweany HC. A fatal case of BesnierBoeck-Schaumann disease with autopsy findings. Ann Intern Med 1941; 15:597-609.

24 Berte SJ, Pfotenhauer MA. Massive pleural effusion in sarcoidosis. Am Rev Respir Dis 1962; 86:261-4.

25 Plancherel B. Sur un cas de pleurésie sarcoïdosique. Med Thorac (Basel) 1963; 20: suppl, 118-21.

26 Silveira J, Benevides W. Pleuraerguss bei Sarkoidose. $Z$ Tuberk 1964; 121:353-55.

27 Lebacq E. La sarcoidose de Besnier-BoeckSchaumann. Paris: Maloine SA, 1964.

28 Kovnat PJ, Donohue RF. Sarcoidosis involving the pleura. Ann Intern Med 1965; 62:120-4.

29 Macquet V, Leduc M, Lafitte P. Pleurésie chronique par sarcoïdose pleurale. Lille Med 1965; 10:207-10.

30 Press P, Junod A, Golay M. Sarcoïdose, pleurésie exsudative et lupus erythemateux discorde. Schweiz Med Wochenschr 1965; 95:1674-77.

31 Selroos O. Exudative pleurisy and sarcoidosis. Br J Dis Chest 1966; 60:191-6.

32 Aberg H, Bah M, Waters AW. Sarcoidosis complicated by chylothorax. Minn Med 1966; 57: 1065-70.

33 Budillon G, Coraggio F, Di Simone A. Sarcoidosi ad impegno pluridistrettuale con large partecipozione della sierose. Riv Anat Patol Oncol 1967; 31:482-94.

34 Everett E, Overholt E. Sarcoidosis and pleural effusion. Milit Med 1968; 133:731-3.

35 Nelson DG, Loudon RG. Sarcoidosis with pleural involvement. Am Rev Respir Dis 1973; 1C8: 647-51. 